\title{
POLSKIE ŚRODOWISKO NAUKOWE W REPUBLICE LITEWSKIEJ
}

ilno, dziś stolica niepodległej Republiki Litewskiej, w okresie międzywojennym było jednym z najważniejszych polskich ośrodków naukowo-akademickich. Kadrę mieszczącego się tam Uniwersytetu Stefana Batorego stanowili profesorowie pochodzący z całej Polski, spośród których wymienić trzeba: Wincentego Lutosławskiego, Mariana Massoniusa, Władysława Tatarkiewicza, Feliksa Konecznego, Stanisława Pigonia, Manfreda Krigla, Konrada Górskiego, Tadeusza Czeżowskiego, Henryka Elzenberga, Stefana Ehrenkreuza, Ferdynanda Ruszczyca.

Przesunięcie granic Polski na zachód po II wojnie światowej spowodowało, że ci, którzy przetrwali lata 1939-1945, znaleźli się w granicach Litewskiej Socjalistycznej Republiki Radzieckiej. Umowa pomiędzy jej rządem a Polskim Komitetem Wyzwolenia Narodowego umożliwiła przesiedlenie (błędnie określane „repatriacją") obywateli przedwojennej Rzeczypospolitej do Polski". Rozpoczynając od wiosny 1945 roku przez następne kilka lat wyjechała z Wileńszczyzny do Polski prawie cała inteligencja. Nieliczni z tej grupy, którzy nie wyjechali, zostali wywiezieni na wschód, jako element antysowiecki. Na miejscu pozostali ci, którzy uwierzyli, że przy władzy radzieckiej ułożą sobie życie i nie będą represjonowani. Dotyczyło to przede wszystkim środowisk robotniczych i chłopskich. Pracownicy naukowi i inni przedstawiciele wileńskiej inteligencji najczęściej decydowali się na wyjazd. Część profesorów i docentów Uniwersytetu Stefana Batorego osiadła w Londynie, gdzie powołano organizację o nazwie Społeczność

Dr Marcin WAKAR jest adiunktem w Ośrodku Badań Naukowych im. Wojciecha Kętrzyńskiego w Olsztynie. marcin.wakar@gmail.com

1 Na mocy kolejnej umowy międzypaństwowej doszło do drugiej fali przesiedleń w latach 1955-1959. 
Akademicka USB². Jednakże większość ocalałej kadry naukowej, administracja i studenci wyjechała do Torunia, gdzie powstał nowy uniwersytet. Tam nowy dom znaleźli: rektor Wacław Dziewulski i prorektor Tadeusz Czeżowski oraz profesorowie: Jan Prüffer, Henryk Elzenberg, Tymon Niesiołowski, Konrad Górski, Jerzy Remer, Wilhelmina Iwanowska, Stefan Srebrny i wielu innych. Uniwersytet Mikołaja Kopernika z dumą podkreśla zawsze ciągłość tradycji z USB ${ }^{3}$. Wyjątkowe są losy dr. Jerzego Ordy, znanego historyka sztuki. Jako jeden z niewielu polskich naukowców pozostał on w Wilnie i choć z jego wiedzy korzystało wielu litewskich uczonych, otrzymał jedynie etat portiera w Litewskiej Akademii Nauk ${ }^{4}$.

W pozbawionej elit ponaddwustutysięcznej społeczności polskiej na Litwie rozpoczął się proces ich odtworzenia. Dziś w niepodlegtej Republice Litewskiej funkcjonuje polskie środowisko naukowe, które skupia się w Wilnie ${ }^{5}$. Powołane przez nie stowarzyszenie liczy 74 członków ze stopniem naukowym doktora lub wyższym ${ }^{6}$. Choć napisano już kilka artykułów o polskich naukowcach na Litwie, dotyczyły one jedynie wybranych środowisk związanych z poszczególnymi ośrodkami akademickimi lub dziedzinami wiedzy. Niniejszy artykuł jest próbą syntezy tych informacji, poszerzoną o własne badania, jakie prowadził autor w czasie trzymiesięcznego stażu naukowego w Instytucie Historii Litwy W Wilnie?. W nie weszła przede wszystkim lektura "Rocznika Stowarzyszenia Naukowców Polaków Litwy" oraz polskojęzycznej prasy wydawanej w Republice Litewskiej, m.in. „Kuriera Wileńskiego”, "Magazynu Wileńskiego” czy organu Związku Polaków na Litwie, „Nasza Gazeta”. Ponadto wyniki kwerendy bibliotecznej wzbogacone zostały przez przeprowadzenie wywiadów pogłębionych z członkami polskiego środowiska naukowego. Wśród nich szczególnie istotnymi okazały się wywiady z dziekanem wileńskiej filii Uniwersytetu w Białymstoku, dr. hab. Jarosławem Wołkonowskim, prof. UwB i doc. dr Ireną Masojć, kierownikiem Katedry Filologii Polskiej i Dydaktyki Litewskiego Uniwersytetu Edukologicznego.

Naukowcy Polacy na Litwie są specjalistami z różnych dziedzin wiedzy, dlatego też związani są z prawie wszystkimi uczelniami wyższymi i instytutami badawczymi stolicy. Spośród nich wymienić trzeba: Uniwersytet Wileński, Litewski Uniwersytet Edukologiczny (dawniej Wileński Uniwersytet Pedagogiczny), Wileński Uniwersytet Techniczny im. Giedymina, Uniwersytet Michała Römera, Akademię Sztuk Pięknych, Litewską Akademię Nauk, Instytut Pracy i Badań Socjalnych, Wileńską Szkołę Technologii, Biznesu i Rolnictwa, Instytut Badań Kultury Litwy, Instytut Fizyki Półprzewodników, czy w końcu wileńską filię Uniwersytetu w Białymstoku (Wydział Ekonomiczno-Informatyczny w Wilnie UwB). Przedstawiciele polskiego środowiska naukowego obecni są również w pozastołecznych ośrodkach akademickich, gtównie na Uniwersytecie Witolda Wielkiego w Kownie.

Większość z litewskich naukowców Polaków zrzeszona jest w Stowarzyszeniu Naukowców Polaków Litwy, które powołane zostało 14 kwietnia 1989 r. ${ }^{8}$ Założycielami Stowarzyszenia była grupa uczonych w składzie: prof. dr hab. Romuald Brazis, prof. dr hab. Edward Szpilewski, dr Emilia Maria Iwaszkiewicz, dr Medard Czobot, dr Wojciech Stankiewicz, dr Jan Ciechanowicz, dr Witold Filistowicz, dr hab. Zygmunt Mackiewicz

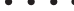

2 M. Jackiewicz, Encyklopedia Ziemi Wileńskiej, t. IX - Nauka i uczeni na Ziemi Wileńskiej od XVI w. do 1945 r., Bydgoszcz 2010, s. 408-409.

lbidem.

A. Srebrakowski, Polacy w Litewskiej SRR 1944-1989, Toruń 2002, s. 105.

Związane jest to z faktem zwartego zamieszkania mniejszości polskiej w Wilnie i okolicach.

Sprawozdanie z działalności Zarządu SNPL za rok 2011, maszynopis, s. 1.

Staż finansowany ze środków Biura Uznawalności Wykształcenia i Współpracy Międzynarodowej autor odbył w okresie od 1 września do 30 listopada 2012 r.

8 Stowarzyszenie Naukowców Polaków Litwy 1989-2002, „Rocznik Stowarzyszenia Naukowców Polaków Litwy", 2001/2002 nr 1, s. 161. 
i dr Eleonora Ciunienè ${ }^{9}$. Za główne kierunki działania Stowarzyszenie przyjęło prowadzenie badań w różnych dziedzinach nauki, wspieranie polskiego szkolnictwa na Litwie i przygotowania na studia uzdolnionej młodzieży, wydawanie literatury naukowo-dydaktycznej i popularyzatorskiej, współpracę z innymi organizacjami naukowymi oraz organizowanie konferencji naukowych, kongresów i konkursów ${ }^{10}$. Tylko w ciągu pierwszych 5 lat działalności 2 członków uzyskało habilitację, 3 doktoraty, zaś na studia doktoranckie i podyplomowe wyjechało do Polski aż 20 członków SNPL ${ }^{11}$. Swą działalność Stowarzyszenie sformalizowało rejestracją w Ministerstwie Sprawiedliwości Republiki Litewskiej dopiero 3 grudnia 1996 r. ${ }^{12}$ Jak podaje Adam Bobryk, powołując się na wywiad z dr. Medardem Czobotem zamieszczony w "Czerwonym Sztandarze”, Stowarzyszenie początkowo zrzeszało blisko 30 naukowców Polaków ${ }^{13}$. W 2002 r. było ich już 48 $8^{14}$, natomiast dziś Stowarzyszenie liczy aż 74 osoby ${ }^{15}$. W okresie 1989-1998 funkcję prezesa SNPL sprawował prof. dr hab. Romuald Brazis, natomiast poczynając od 1998 do 2011 r. - dr hab. Jarosław Wołkonowski, prof. UwB ${ }^{16}$. W kwietniu 2011 r. na prezesa Stowarzyszenia wybrany został prof. Bogusław Grużewski" ${ }^{17}$. Obok niego w skład zarządu weszli: doc. dr Barbara Dwilewicz (zastępca prezesa), dr Ryszard Gaidis (sekretarz naukowy SNPL), dr Łukasz Wardyn, dr Mirosław Szejbak (członek zarządu), dr Henryk Malewski (członek zarządu) i dr Brigita Žuromskaitė (członek zarządu). Obowiązki skarbnika pełni dr hab. Henryka Ilgiewicz ${ }^{18}$. Zarząd Stowarzyszenia wybierany jest raz na trzy lata przez najwyższy organ SNPL - Walne Zgromadzenie Członków, zwoływane przez zarząd przynajmniej raz do roku ${ }^{19}$. Obecnie siedziba Stowarzyszenia znajduje się w Domu Kultury Polskiej przy ulicy Naugarduko (Nowogródzka) $76^{20}$.

Stowarzyszenie Naukowców Polaków Litwy jest organizatorem lub współorganizatorem szeregu konferencji naukowych. Do najważniejszych należy cykl konferencji międzynarodowych "Nauka a jakość życia”. Od początku działalności do 2003 r. włącznie odbyło się ich $8^{21}$, zaś do września 2011 r. - 1522. Obok tego organizowano wiele innych, spośród których wymienić należy: „Wileńszczyzna u progu III Tysiąclecia” (27 listopada 1999)23, „Polsko-litewska lekcja historii" (4 grudnia 1999)24, „Wilno jako ośrodek nauki, kultury i oświaty w XX wieku” (15 listopada 2003)25, „Polska mniejszość na Litwie: stan

14 Lista Stowarzyszenia Naukowców Polaków Litwy 2002, „Rocznik Stowarzyszenia Naukowców Polaków Litwy", 2001/2002 nr 1, s. 163.

15 Sprawozdanie z działalności Zarządu SNPL za rok 2011, maszynopis, s. 1.

16 http://snpl.It/onas.php

17 http://snpl.It/aktualnosci.php

18 http://snpl.It/zarzad.php; Informacja listowna dr hab. Henryki Ilgiewicz z dnia 25 kwietnia 2012 r. (dr hab. Henryka llgiewicz skorygowała błąd ze strony SNPL, na której w składzie zarządu Stowarzyszenia brak dr. Łukasza Wardyna).

19 http://snpl.It/nowystatut.php

20 Ibidem

21 Protokót rocznego zebrania sprawozdawczego Stowarzyszenia Naukowców Polaków Litwy z dnia 9 stycznia 2004 r., "Rocznik Stowarzyszenia Naukowców Polaków Litwy”, 2004 nr 3, s. 195.

22 Informacja podana przez organizatora cyklu, prof. dr. hab. Romualda Brazisa, w wywiadzie z Renata Widtmann, który w ramach cyklu "Życie z pasją" został wyemitowany w „Radiu znad Wilii" 10 września 2011 r. (nagranie w zbiorach autora).

23 Sprawozdanie z działalności Stowarzyszenia Naukowców Polaków Litwy, „Rocznik Stowarzyszenia Naukowców Polaków Litwy", 2001/2002 nr 1, s. 192.

24 Ibidem.

25 Protokót sprawozdawczo-wyborczego zebrania walnego SNPL z dnia 14 stycznia 2005 r., „Rocznik Stowarzyszenia Naukowców Polaków Litwy", 2005 nr 4, s. 195.
} 
i wyzwania na progu Unii Europejskiej” (13 listopada 2004)26, "Zmiany w sytuacji polskiej mniejszości na Litwie po wstąpieniu do UE" (2 grudnia 2006)27. Kolejne konferencje organizowane były wspólnie z wileńską Filią UwB.

W ramach projektu sfinansowanego przez Departament Mniejszości Narodowych i Wychodźstwa RL w 2006 r. została uruchomiona strona internetowa SNPL, która początkowo funkcjonowała pod adresem http://www.republika.pl/snpl ${ }^{28}$, zaś współcześnie znajduje się pod własną domeną http://www.snpl.It/.

Działalność wydawnicza Stowarzyszenia nie opiera się jedynie na publikacji materiatów pokonferencyjnych. Jedną z najważniejszych inicjatyw edytorskich SNPL są "Roczniki Stowarzyszenia Naukowców Polaków Litwy". Do dziś ukazało się 9 numerów pisma, w tym 2 podwójne (2001/2002 nr 1 i 2008/2009 nr 7-8). Pierwszy tom zawierał referaty z konferencji "Język jako podstawa tożsamości”, która odbyła się W Wilnie 17 listopada 2001 r. W późniejszych numerach publikowano zarówno materiały pokonferencyjne, jak i opracowania naukowe z zakresu historii, socjologii, demografii, etnografii, językoznawstwa, ekonomii i informatyki. We wszystkich "Rocznikach..." w formie aneksów zawarte zostały najważniejsze dokumenty Stowarzyszenia, w tym sprawozdania, protokoły i listy członków. Obok tego w każdym prezentowanych jest od kilku do kilkunastu życiorysów członków Stowarzyszenia.

Do najbardziej spektakularnych przedsięwzięć polskiego środowiska naukowego należało z pewnością powołanie Uniwersytetu Polskiego w Wilnie. Po raz pierwszy postulat potrzeby utworzenia takiej uczelni został postawiony przez członków SNPL w trakcie konferencji "Nauka a jakość życia”, która odbyła się w Wilnie w dniach 20-22 września 1990 r. Już 6 października zarząd Stowarzyszenia Naukowców Polaków Litwy powołał grupę inicjatywną do opracowania planu nauczania i statutu uczelni. W jej skład weszli: Romuald Brazis (przewodniczący), Edward Szpilewski, Stanisław Majewski, Ryszard Maciejkianiec, Eugeniusz Wasilewski, Czesław Okińczyc, Medard Czobot, Józef Kwiatkowski, Tadeusz Łozowski i Jan Jaszczanin ${ }^{29}$. Gdy na początku 1991 r. Sejm Republiki Litewskiej uchwalit ustawę "O nauce i studiach" oraz znowelizował ustawę "O mniejszościach narodowych" SNPL, Związek Polaków na Litwie i Fundacja Kultury Polskiej na Litwie im. Józefa Montwiłła wystąpiły do Rady Najwyższej, Rady Ministrów, Ministerstwa Kultury i Oświaty oraz Departamentu Mniejszości Narodowych z pytaniem, czy na podstawie powyższych ustaw można założyć uczelnię wyższą dla potrzeb ludności polskiej zamieszkałej na Litwie. Na to pytanie pozytywnej pisemnej odpowiedzi udzielili zastępca przewodniczącego Rady Najwyższej Republiki Litewskiej Kazimieras Motieka oraz dyrektor generalny ds. Departamentu Narodowości Halina Kobeckaitė ${ }^{30}$. Było jednak zastrzeżenie, iż należy wystąpić u udzielenie licencji na nadawanie stopni naukowych. Wszystkie wymagane dokumenty grupa inicjatywna złożyła latem $1991 r^{31}{ }^{31}$ Jeszcze $w$ lipcu tego roku chęć studiowania zgłosiło ok. 250 osób, mimo iż jak stwierdził prof. Romuald Brazis, „poszczególne osoby i ugrupowania z różnych powodów usiłują przeszkodzić rejestracji statutu i udzieleniu przez rząd licencji Uniwersytetowi"32.

26 Ibidem

27 Protokót Zebrania Walnego Stowarzyszenia Naukowców Polaków Litwy z dnia 27 kwietnia 2007 r., "Rocznik Stowarzyszenia Naukowców Polaków Litwy", 2007 nr 6, s. 193.

28 Ibidem.

29 A. Bobryk, op. cit., s. 267.

30 W sprawie Uniwersytetu Polskiego w Wilnie, „Kurier Wileński”, 9 kwietnia 1991 nr 67, s. 1.

31 A. Bobryk, op. cit., s. 267.

32 R. Brazis, Universitas Polonorum Vilensis, „Kurier Wileński”, 20 lipca 1991 nr 140, s. 2. 
Pierwszy rok akademicki rozpoczął się 3 października 1991 r., a studia podjęło (prawdopodobnie z powodu braku rejestracji uczelni) tylko 150 studentów ${ }^{33}$. Edward Szpilewski informował o działalności Uniwersytetu społeczność polską na łamach „Kuriera Wileńskiego":

„Wykładowcy są zrzeszeni w sześciu katedrach: matematyki i informatyki, fizyki i ekologii, ekonomii i prawa, wzornictwa przemysłowego, biologii i WF oraz nauk społecznych. Studenci mają do wyboru wydziały - humanistyczny z kierunkiem studiów: wychowanie przedszkolne, wzornictwo przemysłowe i plastyka, język angielski i język niemiecki; ekonomii z kierunkiem ekonomii i zarządzania oraz prawa i administracji; przyrodniczy z kierunkiem: informatyki stosowanej, biologii i WF oraz wydziat medyczny z kierunkiem leczniczym i stomatologicznym" ${ }^{34}$.

Początkowo, z braku własnego budynku, zajęcia odbywały się w wileńskich szkołach: im. A. Mickiewicza, im. W. Syrokomli oraz w szkole nr $5^{35}$.

W związku z faktem, iż Wydział Medyczny nie posiadał odpowiedniego zaplecza dydaktycznego, co spotkało się z krytyką środowisk lekarskich w Polsce, w następnym roku studenci zostali przeniesieni do Polski. Dwudziestu pięciu z nich podjęło edukację na Akademii Medycznej w Białymstoku, zaś 5 w Gdańsku³.

W drugim roku, najprawdopodobniej z tej samej przyczyny, na UPW zgłosiło się jeszcze mniej chętnych i na studia przyjęto jedynie 40 osób, zaś kilkunastu chętnym zaproponowano wydział przygotowawczy ${ }^{37}$.

W związku z brakiem rejestracji uczelni, we wrześniu 1993 r. sejmowy Komitet Oświaty, Nauki i Kultury wezwał rząd do zakazania działalności UPW oraz innym uczelniom, które nie zdobyły stosownych zezwoleń. Litewscy parlamentarzyści przekonywali, że funkcjonowanie uczelni jest naruszeniem poprawki do ustawy "O oświacie" z 16 lipca 1993 r., zabraniającej organizowania naboru i prowadzenia dydaktyki w placówkach nieposiadających odpowiednich licencji. Uznali ponadto, iż zakładanie wyższych szkół narodowościowych utrudnia integrowanie się społeczeństwa kraju ${ }^{38} .12$ października 1993 r. rektor UPW, prof. dr hab. Romuald Brazis, prezes Frakcji Związku Polaków na Litwie w Sejmie RL Ryszard Maciejkianiec oraz posłowie Medard Czobot i Artur Płokszto spotkali się z ówczesnym prezydentem Republiki Litewskiej Algirdasem Brazauskasem, któremu zwrócili uwage na fakt, iż niemożliwe jest zastosowanie w praktyce przyjętej poprawki ze względu na brak przepisów wykonawczych ${ }^{39}$. Niedługo po spotkaniu ukazała się uchwała Rządu RL nr 768, która precyzowała postępowanie w tej kwestii, choć wiele zapisów w niej zawartych zawierało sformułowania pozwalające na dość swobodną interpretację. Szczegółowo jednak określono w niej wymagania kadrowe. Połowa pracowników dydaktycznych powinna posiadać stopnie naukowe, a dziesiątą ich część muszą stanowić osoby z tytułem profesorskim. Choć UPW, jak twierdził Romuald Brazis, spełniał te wymagania, to wciąż nie uzyskiwał stosownych pozwoleń, co podyktowane było uwarunkowaniami politycznymi i brakiem dobrej woli władz ${ }^{40}$.

W związku z faktem, iż Uniwersytet Polski w Wilnie nie zaprzestał działalności, 17 września 1996 r. sejmowy Komitet Oświaty, Kultury i Nauki zdecydował się zwrócić do Prokuratury Generalnej, Ministerstwa Oświaty, Nauki i Kultury oraz Ministerstwa Sprawiedliwości RL z inicjatywą natychmiastowego zamknięcia polskiej uczelni $w$ Wilnie ${ }^{41}$.

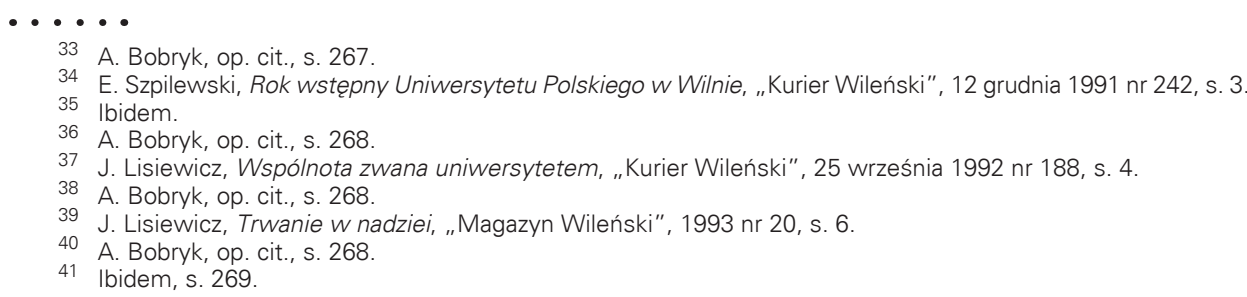


W odpowiedzi w środowisku naukowym związanym z UPW zdecydowano o podjęciu próby rejestracji uczelni w oparciu o jakąkolwiek ustawę litewską, co udało się dopiero 18 maja 1998 r. Wówczas w samorządzie miasta Wilna zarejestrowano instytucję wyższej użyteczności publicznej (lit. viešoji įstaiga) pod łacińską nazwą Universitas Studiorum Polona Vilensis, która rozpoczęła działalność w oparciu o ustawę „O instytucjach publicznych". Niestety nie uzyskała ona pozwolenia na nadawanie stopni naukowych ${ }^{42}$.

Kłopoty uczelni związane z niedoborem specjalistycznej kadry akademickiej, problemami lokalowymi i finansowymi doprowadziły do stopniowego ograniczania kierunków studiów oraz potrzeby reorganizacji uczelni. Jeszcze w 1997 r. na bazie dotychczasowych wydziałów utworzono jeden - Wydział Humanistyczny, na którym kształcić się mogli dydaktycy nauczania początkowego, prawnicy oraz ekonomiści. Mimo braku uprawnień do nadawania stopni naukowych, młodzież kształcąca się na UPW, a później USPV mogła uzyskiwać tytuł magistra dzięki stosownym umowom podpisanym z uczelniami wyższymi w Polsce. Po trzyletnich studiach na polskiej uczelni w Wilnie wyjeżdżali oni do Polski, gdzie kontynuowali naukę i uzyskiwali tytuł magistra ${ }^{43}$. Władze litewskie jednak nie uznawały tych dyplomów, twierdząc, że lata studiów na USPV są niezgodne z prawem litewskim i domagały się powtórzenia tych studiów na legalnej uczelni Litwy lub Polski. Ten stan pozostał do chwili obecnej ${ }^{44}$.

Z czasem ponownie zmieniono ofertę edukacyjną, co obrazuje poniższa tabela.

Tabela 1. Kierunki kształcenia na USPV w roku akademickim 2001/02

\begin{tabular}{|c|c|c|c|c|}
\hline Kierunek & Rok studiów & $\begin{array}{l}\text { Liczba } \\
\text { studentów, } \\
\text { słuchaczy }\end{array}$ & $\begin{array}{c}\text { Liczba } \\
\text { wykładowców }\end{array}$ & $\begin{array}{c}\text { Patronująca uczelnia } \\
\text { w Polsce }\end{array}$ \\
\hline Pedagogika & I, II, III & 20 & 31 & $\begin{array}{l}\text { Akademia Podlaska } \\
\text { w Siedlcach }\end{array}$ \\
\hline Ekonomia & I, II & 53 & 14 & $\begin{array}{l}\text { Uniwersytet } \\
\text { w Białymstoku }\end{array}$ \\
\hline $\begin{array}{l}\text { Zarządzanie } \\
\text { i marketing }\end{array}$ & III & 26 & 12 & $\begin{array}{l}\text { Uniwersytet Mikołaja } \\
\text { Kopernika w Toruniu }\end{array}$ \\
\hline $\begin{array}{l}\text { Ogólne } \\
\text { zarządzanie } \\
\text { biznesem }\end{array}$ & kurs półroczny & 42 & 11 & $\begin{array}{l}\text { Uniwersytet Gdański, } \\
\text { Towarzystwo Miłośników } \\
\text { Wilna i Ziemi Wileńskiej, } \\
\text { oddział w Gdańsku }\end{array}$ \\
\hline $\begin{array}{l}\text { Wstęp do } \\
\text { komputerów }\end{array}$ & $\begin{array}{l}\text { kurs } \\
\text { dwudziestodniowy }\end{array}$ & 70 & 1 & - \\
\hline Plastyka & kurs dwumiesięczny & 3 & 1 & $\begin{array}{l}\text { Instytut Sztuki } \\
\text { Uniwersytetu Śląskiego }\end{array}$ \\
\hline $\begin{array}{l}\text { Historia } \\
\text { najnowsza } \\
\text { państwa i kultury } \\
\text { polskiej }\end{array}$ & $\begin{array}{l}\text { kurs } \\
\text { dziesięciodniowy }\end{array}$ & 400 & 3 & $\begin{array}{l}\text { Towarzystwo Miłośników } \\
\text { Wilna i Ziemi Wileńskiej, } \\
\text { oddział w Krakowie }\end{array}$ \\
\hline
\end{tabular}

Źr ó dło: R. Brazis, Spoteczny Uniwersytet Polski w Wilnie jako praktyczna próba realizacji prawa człowieka do edukacji w niepodległej Republice Litewskiej, [w:] Prawa i wolności człowieka w edukacji demokratycznego państwa. Teoria i jej zastosowanie, pod red. R. Rosy, Siedlce 2003, s. 14.

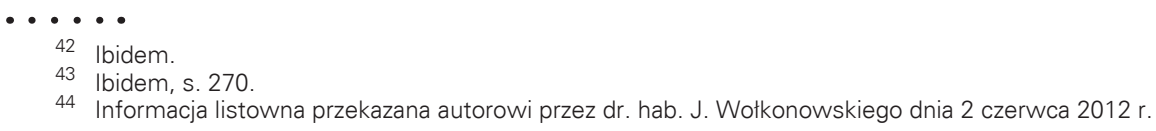

44 Informacja listowna przekazana autorowi przez dr. hab. J. Wołkonowskiego dnia 2 czerwca 2012 r. 
Potrzeby uczelni związane z możliwością nadawania tytułów naukowych scharakteryzował Romuald Brazis:

„Do uzyskania uprawnień dyplomowania należy uporać się z nadzwyczaj trudnym zadaniem. Otóż nawet na jeden kierunek studiów podstawowych (na poziomie bakałarza [odpowiednik polskiego licencjata - przyp. M. Wakar]) wymagane jest zatrudnienie na pierwszym etacie co najmniej dziesięciu pracowników naukowych ze stopniem doktora i doktora habilitowanego. Choć pracuje u nas kilkadziesiąt naukowców [w tym część dojeżdżających z Polski - przyp. M. Wakar], nie są to pracownicy naukowi. Potrzebne są środki na zatrudnienie stałej kadry. Dzięki naszej działalności promocyjnej stopień doktora nauk w Polsce uzyskało około 20 osób. Młodzi doktorzy nauk są i po studiach na uczelniach litewskich. Niestety brak jest funduszy na ich zatrudnienie na USPV"45.

Ważnym osiągnięciem Universitas Studiorum Polona Vilensis było uzyskanie zaplecza w postaci biblioteki, sprzętu komputerowego, dwupokojowego mieszkania służbowego i przede wszystkim własnych budynków przy ul. Aguonų (Makowej) 22 w Wilnie ${ }^{46}$. Wydawany był również periodyk naukowy "Studia Vilnense". Niestety USPV nie udało się uzyskać koniecznych pozwoleń i w połowie ubiegłego dziesięciolecia zaprzestano działalności dydaktycznej. W związku z powołaniem w Wilnie Wydziału Zamiejscowego Uniwersytetu w Białymstoku (o czym w dalszej części niniejszego opracowania) Stowarzyszenie Naukowców Polaków Litwy podjęło w 2008 r. uchwałę o przekazaniu majątku uczelni Uniwersytetowi w Białymstoku na potrzeby Wydziału EkonomicznoInformatycznego w Wilnie. Obecnie USPV jest w trakcie zamykania działalności, choć organizowane są pod auspicjami tego ośrodka konferencje i sporadycznie ukazują się publikacje $e^{47}$.

Niezależnie od działań skierowanych na rozwój USPV na początku 2003 r. Stowarzyszenie Naukowców Polaków Litwy podjęło działania na rzecz utworzenia w Wilnie filii zagranicznej polskiej uczelni wyższej. Podstawowym argumentem według SNPL był dwukrotnie niższy wskaźnik wyższego wykształcenia polskiej mniejszości na Litwie (63) w porównaniu do krajowego (126 osób z wyższym wykształceniem na 1000 mieszkańców Litwy według spisu ludności z 2001 r.). Polska mniejszość na Litwie zajmowała przedostatnią pozycję - przed mniejszością romską, ustępując znacznie mniejszości rosyjskiej, białoruskiej, ukraińskiej, żydowskiej i innym. W drugiej połowie marca 2003 r. SNPL zwróciło się z prośbą o poparcie w tej kwestii do Zarządu Głównego Związku Polaków na Litwie, Stowarzyszenia "Macierz Szkolna” i Domu Kultury Polskiej w Wilnie. Napłynęły pozytywne odpowiedzi ${ }^{48}$. Szczególnie ważne było błyskawiczne poparcie Związku Polaków na Litwie. W piśmie Zarządu Głównego ZPL (podpisanym przez prezesa Michała Mackiewicza) do prezesa SNPL z 24 marca przeczytać można m.in.:

„W odpowiedzi na Pana pismo z 18 marca 2003 r. pragnę zaznaczyć, że Zarząd Główny Związku Polaków na Litwie rozpatrzył kwestię powołania jednostki wyższej uczelni RP i zgodnie z Uchwałą 2.1. z dn. 20 marca 2003 r. popiera inicjatywę powołania w naszym kraju jednostki zagranicznej wyższej uczelni polskiej. Pokładamy nadzieję, że inicjatywa pomyślnie dojdzie do skutku i w naszym kraju zostanie powołana prawnie działająca uczelnia z polskim językiem wy-

45 R. Brazis, Społeczny Uniwersytet Polski w Wilnie jako praktyczna próba realizacji prawa człowieka do edukacji w niepodległej Republice Litewskiej, [w:] Prawa i wolności człowieka w edukacji demokratycznego państwa. Teoria i jej zastosowanie, pod red. R. Rosy, Siedlce 2003, s. 14.

46 Ibidem, s. 10

47 Informacja ustna przekazana autorowi przez dr. hab. Jarosława Wołkonowskiego, prof. UwB, dnia 27 września 2011 r. w Wilnie.

48 J. Wołkonowski, Powołanie Filii w Wilnie Uniwersytetu w Białymstoku: od zainicjowania do pierwszych miesięcy działalności, „Rocznik Stowarzyszenia Naukowców Polaków Litwy”, 2007 nr 6, s. 46. 
kładowym; wiąże się to bowiem z zapobieganiem emigracji młodzieży polskiej z Litwy, gdyż po ukończeniu kierunku studiów ich dyplomy zostaną nostryfikowane" 49 .

Zaraz potem przedstawiciele SNPL podjęli rozmowy z władzami Uniwersytetu w Białymstoku oraz czołowymi politykami polskimi i litewskimi. Przeprowadzono także rozmowy z przedstawicielami Uniwersytetu Mikołaja Kopernika w Toruniu, Uniwersytetu Gdańskiego i Szkoły Głównej Handlowej w Warszawie. Każda z tych uczelni widziała inne rozwiązania - od studiów podyplomowych, które proponował UG, po studia w języku angielskim, jakie proponowała SGH. Najlepszą ofertę złożył Uniwersytet w Białymstoku, z którym SNPL nawiązało ścisłą współpracę. Owocem rozmów była uchwała Senatu Uniwersytetu w Białymstoku nr 222, w której zadeklarowano podjęcie prac organizacyjnych mających na celu utworzenie filii uczelni w Wilnie (kierunki: ekonomia i informatyka) ${ }^{50}$. W związku z wysokimi wymaganiami dotyczącymi otwarcia filii, 27 września 2004 r. senat UwB zadecydował o podjęciu działań w celu utworzenia wydziału zamiejscowego (według prawa polskiego filia może powstać kiedy są m.in. dwa wydziały, zatem według prawa polskiego chciano utworzyć „wydział zamiejscowy”, natomiast według prawa litewskiego „filię"). W uchwale nr 267 przeczytać można:

„Senat Uniwersytetu w Białymstoku, biorąc pod uwage prośby skierowane przez środowisko polonijne Litwy, wyraża gotowość utworzenia zamiejscowego Wydziału Ekonomiczno-Informatycznego w Wilnie. Obecnie możliwe jest z naszej strony podjęcie ksztatcenia w ramach wyższych studiów zawodowych na dwu kierunkach: ekonomii i informatyce" ${ }^{51}$.

Lata 2004-2006 upłynęły na przygotowaniu (przez UwB i SNPL) i w końcu zatwierdzeniu dokumentacji przez Ministerstwo Edukacji Narodowej RP oraz Państwową Komisję Akredytacyjną. Po otrzymaniu zgody na otwarcie wydziału zamiejscowego zespół członków SNPL w składzie: dr Alina Grynia, dr Krystyna Łapin, dr Mirosław Szejbak i dr hab. Jarosław Wołkonowski przygotował liczącą ponad osiemset stron dokumentację w języku litewskim. Po miesiącach starań udało się dopełnić wszystkich formalności i mimo kilku nieprzychylnych opinii środowisk litewskich Rząd RL na posiedzeniu 19 czerwca 2007 r. wydał zgodę na powołanie wileńskiej filii Uniwersytetu w Białymstoku ${ }^{52}$. Niespełna miesiąc później (6 lipca 2007 r.) wybrane zostały władze Wydziału Ekonomiczno-Informatycznego w składzie: dr hab. Jarosław Wołkonowski, prof. UwB - dziekan, dr Alina Grynia - prodziekan; oraz Rada Wydziału w składzie: prof. dr hab. Janusz Kaliński, prof. dr hab. Czestaw Noniewicz, dr hab. Edward Szpilewski, prof. UwB, dr hab. Kazimierz Trzęsicki, prof. UwB, dr hab. Aleksander Maksimczuk, prof. UwB, dr hab. Barys Labanau, prof. UwB, dr hab. Jarosław Wołkonowski, prof. UwB, dr hab. Anna Chmielak, prof. UwB, dr Alina Grynia, dr Krystina Łapin i dr Aleksander Buczacki ${ }^{53}$.

Po przekazaniu informacji o władzach wydziału instytucjom litewskim placówka została zarejestrowana jako filia zagranicznego podmiotu prawnego w Krajowym Centrum Rejestru Podmiotów Prawnych pod numerem Regon 300975749, 8 sierpnia uzyskała licencję Ministerstwa Oświaty i Nauki Republiki Litewskiej nr 002011 na prowadzenie studiów licencjackich na kierunkach Ekonomia i Informatyka ${ }^{54}$.

49 Pismo prezesa ZG ZLP Macieja Mackiewicza do prezesa SNPL dr. Jarosława Wotkonowskiego z dnia 24 marca 2003 r., „Rocznik Stowarzyszenia Naukowców Polaków Litwy”, 2003 nr 2, s. 194

50 J. Wołkonowski, Powołanie Filii w Wilnie Uniwersytetu w Białymstoku..., op. cit., s. 46-47.

51 Uchwała Senatu UwB nr 267 "W sprawie utworzenia wydziału zamiejscowego w Bialymstoku”, cyt. za: J. Wotkonowski, Powołanie Filii w Wilnie Uniwersytetu w Biatymstoku..., op. cit., s. 64

52 J. Wołkonowski, Powołanie Filii w Wilnie Uniwersytetu w Białymstoku..., op. cit., s. 58.

53 Ibidem, s. 59

54 Ibidem. 
Pierwsza rekrutacja była utrudniona przez fakt, iż została ogłoszona 2 tygodnie po ukończeniu rekrutacji na litewskie uczelnie. Mimo to zgłosiło się ponad 200 kandydatów, z czego przyjętych zostało 177: 124 na ekonomię i 53 na informatykę ${ }^{55}$.

27 lipca 2010 r. odbyło się pierwsze wręczenie dyplomów licencjackich. Uroczystość, podobnie jak inauguracja pierwszego roku akademickiego, odbyła się w Domu Kultury Polskiej w Wilnie. Otrzymało je 39 osób, które pomyślnie ukończyły trzyletnie studia: 34 na kierunku ekonomia, a 5 na informatyce. Pozostałe 41 osób otrzymało dyplom na jesieni, ponieważ obrona prac z różnych powodów się przeciągnęła ${ }^{56}$. Ogółem do wiosny 2012 r. Wydział Ekonomiczno-Informatyczny ukończyło 145 absolwentów, ich dyplomy zostały uznane i nostryfikowane przez władze litewskie. Według Ministerstwa Oświaty i Nauki Litwy żaden z absolwentów Wydziału Ekonomiczno-Informatycznego nie zarejestrował się na giełdach pracy na Litwie, co oznacza, że absolwenci Wydziału znaleźli zatrudnienie na Litwie lub w innych krajach europejskich, zaś około 35 osób wyjechało na studia magisterskie do Polski.

Na Wydziale rozpoczęto aktywną działalność naukową. Siedmiu asystentów - pracowników naukowo-dydaktycznych pisze prace doktorskie, dwie z nich są już na etapie obrony. W stopniu zaawansowanym jest również jedna praca habilitacyjna. Corocznie odbywają się na Wydziale międzynarodowe konferencje naukowe. Ukazały się dwie pozycje wydawnicze pod naukową redakcją dr A. Gryni, Rola kapitału intelektualnego w rozwoju gospodarki opartej na wiedzy oraz Wptyw światowego kryzysu gospodarczego na kraje Europy Środkowo-Wschodniej. Aspekty gospodarcze i społeczne ${ }^{57}$.

Dzięki aktywności władz Wydziału udało się od władz Litwy uzyskać zniżki na transport dla studentów oraz, dzięki ingerencji Komisji Europejskiej, stypendia socjalne i kredyty na studia na tych samych warunkach, jakie mają studenci na litewskich uczelniach. Od roku akademickiego 2011/12 studenci UwB mogli już ubiegać się o tzw. „koszyk studenta”, czyli częściowe finansowanie studiów, przeznaczone dla najlepszych studentów z puli określonej przez ministerstwo (taki „koszyk studenta” otrzymało 7 studentów podczas rekrutacji w 2011 r.). W maju 2011 r. rozwiązany został problem włączenia filii w elektroniczny system rekrutacyjny, czego do niedawna odmawiały władze litewskie, argumentując, że uczelnia zagraniczna nie może zostać nim objęta. Filia UwB może się również ubiegać o fundusze unijne przeznaczone dla Litwy. Problemem wciąż pozostaje kwestia budynku. Aktualnie uczelnia swą siedzibę ma w Domu Kultury Polskiej, zaś większość zajęć prowadzona jest w wynajmowanych pomieszczeniach przy ul. Kalvariijų (Kalwaryjskiej) 143. Przekazany przez USPV budynek przy ul. Aguonuc (Makowej) 22 wraz z 14-arową dziatką nie spełnia wszystkich wymagań prawa litewskiego (problem z miejscami parkingowymi), gdyż można tutaj zbudować siedzibę o powierzchni 3300 m², zaś prawo litewskie określiło w 2011 r. powierzchnię na jednego studenta 8,4 m², co dla filii oznacza dysponowanie budynkiem o powierzchni $4200 \mathrm{~m}^{2}$. Przygotowano już jednak projekt rozbudowy i otrzymano stosowne zezwolenia, jednak nie rozpoczęto budowy, gdyż nowy budynek będzie za mały. Z prośbą o wsparcie finansowe na zakup większej działki i zbudowanie odpowiedniej siedziby zwracano się wiele razy do władz RP, jednak problem nie został rozwiązany ${ }^{58}$.

Planowane jest też rozszerzenie oferty dydaktycznej o kierunki humanistyczne: europeistykę i stosunki międzynarodowe. Ich powstanie przy wileńskiej filii UwB zdecydowania 2011 r. w Wilnie.
} 
nie zwiększyłoby konkurencyjność uczelni na litewskim rynku edukacyjnym ${ }^{59}$. Miałoby to również wpływ na kierunek rozwoju polskiego środowiska naukowego w tym kraju.

Aktualnie w wileńskiej filii UwB studiuje 521 studentów, z czego 377 na kierunku ekonomia i 144 na informatyce. Uczelnia zatrudnia ok. 30 przedstawicieli polskiego środowiska naukowego w Wilnie, w tym 20 na pełnym etacie. Dodatkowo 45 wykładowców dojeżdża z Białegostoku. Na Wydziale prężnie działa Studenckie Koło Naukowe Ekonomistów im. F.A. Hayeka pod opieką naukową dr A. Gryni, powstało też Studenckie Koło Naukowe Informatyków im. J. Neumanna pod opieką naukową dr. R. Łaptika ${ }^{60}$. Z inicjatywy Studenckiego Koła Naukowego Ekonomistów 17 maja 2012 r. odbyła się I Międzynarodowa Konferencja Studencka pt. „Czy dyplom wyższego wykształcenia traci na znaczeniu?", która cieszyła się dużym zainteresowaniem młodzieży i mediów61.

Innym ośrodkiem skupiającym w Wilnie polskie środowisko naukowe jest Centrum Polonistyczne (Polonistikos Centras) na Uniwersytecie Wileńskim. Do jego utworzenia dążono już od 1988 r., kiedy porozumienie w tej sprawie zawarło Ministerstwo Edukacji Narodowej PRL z władzami Związku Radzieckiego. Niestety nie zrealizowano tych planów, choć strona polska otworzyła 1 października 1988 r. lituanistykę na Uniwersytecie im. Adama Mickiewicza w Poznaniu. Swoistą namiastką było powołanie w 1989 r. Katedry Filologii Słowiańskiej, która miała w planach badanie kontaktów polsko-litewskich w sferze językowej62. Takie połowiczne rozwiązanie nie satysfakcjonowało mniejszości polskiej. Interwencję w tej sprawie podjęło polskie MSZ 26 listopada 1990 r. Plany udało się zrealizować dopiero 1 września 1993 r., kiedy na Uniwersytecie Wileńskim otwarto Katedre Języka Polskiego i Literatury. Jej kierownikiem został litewski badacz języka polskiego i litewskiego dr Algis Kaleda (obecnie prof. dr hab.). Pierwszy rok studiów rozpoczęły wówczas 22 osoby w 2 grupach. Do jednej uczęszczali absolwenci szkół polskich, do drugiej zaś absolwenci szkół litewskich i rosyjskich. Pierwsza promocja odbyła się 21 czerwca 1997 r., gdy 18 studentów otrzymało tytuł bakałarza63. Dwa lata później odbyły się pierwsze obrony prac magisterskich. Wraz z magistrami pojawili się wśród pracowników pierwsi doktorzy: Wiktoria Ušinskienė (praca obroniona na Uniwersytecie Wileńskim), Krystyna Rutkowska i Mirosław Dawlewicz (prace obronione na Uniwersytecie Warszawskim) ${ }^{64}$. W 2007 r. Katedrę Języka Polskiego i Literatury przekształcono (w ramach reorganizacji Wydziału Filologicznego) w Centrum Polonistyczne, którego kierownikiem został doc. dr Mirosław Dawlewicz. Podstawowe cele działalności Centrum charakteryzuje on następująco:

„1. kształcenie specjalistów w zakresie polskiej literatury, kultury oraz języka placówkom oświatowym, kulturalnym oraz państwowym;

2. rozwijanie badań naukowych: badania nad obecnością literatury i kultury polskiej na Litwie, analizowanie litewsko-polskich związków literackich, funkcjonowanie języka polskiego na Litwie, przygotowywanie prac naukowych;

3. rozwijanie i popieranie wszechstronnej polsko-litewskiej współpracy kulturalnej"65.

\section{......}

59 A. Grynia, Ksztaltowanie pozycji konkurencyjnej szkoły wyższej na rynku krajowym i zagranicznym, „Rocznik Stowarzyszenia Naukowców Polaków Litwy", 2008/2009 nr 7-8, s. 228-229.

60 Informacja ustna przekazana autorowi przez dr. hab. Jarosława Wołkonowskiego, prof. UwB, dnia 27 września 2011 r. w Wilnie.

61 http://www.uwb.lt/knse/konferencjastud/index.html

62 A. Bobryk, op. cit., s. 271

63 Ibidem, s. 272.

64 M. Dawlewicz, Dzieje i wspótczesność polonistyki Uniwersytetu Wileńskiego. Wspótpraca z zagranicą, [w:] Europejskość ojczyzn. Litewsko-polskie związki kulturowe i językowe, pod red. M. Dawlewicza, Wilno 2009, s. 326-327.

65 Ibidem, s. 325. 
W ciągu pierwszych 15 lat działalności Centrum Polonistycznego dyplomy filologa polonisty z tytułem bakałarza otrzymało 231 absolwentów. Wśród nich, do końca 2008 r. 5 osób obroniło dysertacje doktorskie: Natalia Mażulis, Wioleta Żakiewicz, Halina Gierasimowicz-Kamczycka, Barbara Dawidowicz i Maksim Duszkin ${ }^{66}$.

Centrum Polonistyczne prowadzi szeroką działalność badawczą głównie z zakresu językoznawstwa ze szczególnym uwzględnieniem socjolingwistyki. Od 1995 r. poloniści z Uniwersytetu Wileńskiego (we współpracy z prof. dr hab. Haliną Karaś z Uniwersytetu Warszawskiego) biorą udział w obozach dialektologicznych, w trakcie których zbierają materiał językowy. Do 2009 r. odbyło się 14 takich ekspedycji, a zbadano dialekty z rejonów: wileńskiego, solecznickiego, święciańskiego, kiejdańskiego, ignalińskiego i jezioroskiego. Oprócz tego zebrano materiał językowy z okolic Janowa i Wiłkomierza. Owocem powyższych ekspedycji naukowych jest publikacja zbiorowa Język polski na Kowieńszczyźnie. Historia - sytuacja socjolingwistyczna - cechy jezzykowe - teksty, wydana w 2001 r. Obok tego, z zakresu językoznawstwa, opublikowano jeszcze wiele innych prac zbiorowych, spośród których wymienić można: Z zagadnień leksyki gwar polskich okolic Niemenczyna i Mejszagoły (na materiale obrzędów żniwnych) (1997); Język wybranych dokumentów historycznych z parafii ejszyskiej (fonetyka, morfologia, słownictwo) (1998); Jezzyk najstarszego pokolenia wsi Miedniki (2003); Lituanizmy leksykalne w gwarach polskich Wileńszczyzny $(2007)^{67}$

W Centrum Polonistycznym Uniwersytetu Wileńskiego prowadzone są również prace badawcze z zakresu literaturoznawstwa, przede wszystkim wokół literatury romantycznej i polsko-litewskich związków literackich. Z publikacji wymienić można: A. Kalėdy Powojenna literatura litewska: droga strat i nadziei (1998); Dzieje literatury litewskiej 1918-2000 (2003); Ireny Fedorowicz Czesław Jankowski (1857-1929) w życiu literacko-kulturalnym Wilna lat 1905-1929 (Kraków 2003), czy wreszcie prace zbiorową Wileńskie konteksty romantyczne (1995). Prowadzone są również prace translacyjne. Przełożone na język litewski zostały Poezje i Dolina Issy Czesława Miłosza, a także Poezje Wisławy Szymborskiej ${ }^{68}$.

Z kolei zagadnieniom kultury języka polskiego na Wileńszczyźnie poświęcono kilka prac dyplomowych, m.in.: „Formy grzecznościowe w polszczyźnie wileńskiej na tle polszczyzny ogólnej” (1997); „Błędy językowe w prasie wileńskiej („Kurier Wileński «, "Nasza Gazeta«)" (1999); „Z zagadnień sprawności fleksyjnej studentów polonistyki UW. Analiza językowa" (2007) ${ }^{69}$.

Do dziś studia polonistyczne na Uniwersytecie Wileńskim ukończyło ok. 300 absolwentów. W 2009 r. w związku z reformą szkolnictwa wyższego (wysokie opłaty za studia, gdy kandydat nie wejdzie do puli tych, którzy otrzymują tzw. „koszyk studenta”), zabrakło studentów, którzy chcieliby studiować filologię polską (potrzeba min. 8 osób, aby otworzyć rok). W tym samym roku otwarto filologię litewską z językiem polskim. Niestety na nią również zabrakło chętnych. W związku z powyższym w ogóle zrezygnowano z ogłaszania naboru na I rok. Jako filologia polska jest obecnie tylko IV rok. Mimo to prowadzone są zajęcia dla studentów innych kierunków. Aktualnie w Centrum Polonistycznym zatrudnionych jest 9 osób, z czego 6 reprezentuje polskie środowisko naukowe w Wilnie. Są to: doc. dr Mirosław Dawlewicz, dr Teresa Dalecka, doc. dr Irena Fedorowicz, dr Krystyna Rutkowska, dr Kinga Geben oraz doc. dr Regina Jakubenas. Pozostali pracownicy to dwoje Litwinów (w tym jedna osoba z Puńska): prof. dr hab. Algis Kalèda, dr Danuta

66 I. Fedorowicz, 15-lecie polonistyki na Uniwersytecie Wileńskim, AIMW, www.magwil.It, 2008 nr 12.

67 M. Dawlewicz, op. cit., s. 328-329.

68 Ibidem, s. 327-328.

69 Ibidem, s. 329. 
Balašaitienè, oraz Rosjanka doc. dr Wiktoria Ušinkiené70. We wrześniu 2012 r. na kierownika Centrum Polonistycznego wybrany został prof. dr hab. Algis Kalèda ${ }^{71}$.

Najbardziej zasłużoną dla polskiego środowiska naukowego na Litwie placówką jest Katedra Filologii Polskiej i Dydaktyki, działająca na Wydziale Filologicznym Litewskiego Uniwersytetu Edukologicznego (do 1992 r. Wileńskiego Państwowego Instytutu Pedagogicznego, a do 2011 r. Wileńskiego Uniwersytetu Pedagogicznego). Założona została już w 1961 r. (choć jej korzenie sięgają 1951 r., kiedy w Nowej Wilejce powstał Instytut Nauczycielski²). Pierwszymi pracownikami Wydziału Polonistyki, a następnie, po włączeniu w struktury Wydziału Języków Obcych, Katedry Języka Polskiego i Literatury na WPIP byli: Irina Kaszkarowa, Genadiusz Rakitski, Anna Kaupuż, Margarita Lemberg, Maria Niedźwiedzka. Wieloletnim dziekanem Wydziału Polonistyki, a od 1969 r. prodziekanem Wydziału Języków Obcych był pochodzący z Białorusi Polak, Włodzimierz Czeczot ${ }^{73}$.

Na przełomie lat osiemdziesiątych i dziewięćdziesiątych ubiegłego wieku nastąpiła wymiana kadr na polonistyce Wileńskiego Państwowego Instytutu Pedagogicznego. Starsi pracownicy odeszli na emeryturę, a ich miejsce zajęli wychowankowie polonistyki: Halina Turkiewicz, Romuald Naruniec, Irena Masojć, Krystyna Syrnicka, Henryka Sokołowska, Jan Sawicki i Józef Szostakowski. Dołączyła do nich pochodząca z Wileńszczyzny absolwentka Uniwersytetu Jagiellońskiego w Krakowie - Barbara Dwilewicz. Nowym kierownikiem katedry została Halina Turkiewicz, a od 2004 r. Irena Masojć74.

W 1990 r., na fali przemian społeczno-politycznych, jakie miały miejsce na Litwie, Katedra Języka Polskiego i Literatury weszła w skład Wydziału Mniejszości Narodowych Litwy. Ze względu na fakt, iż obok polonistyki rozwinął się tylko jeden kierunek - białorutenistyka, został on połączony z Wydziałem Języka Rosyjskiego i Literatury, tworząc Wydział Slawistyki. W 1992 r. uczelnia została przemianowana na Wileński Uniwersytet Pedagogiczny ${ }^{75}$. W 2009 r. polonistyka, jako Katedra Filologii Polskiej i Dydaktyki, weszła w skład Wydziału Filologicznego ${ }^{76}$. We wrześniu 2012 r. Katedra została przemianowana na Centrum Języka Polskiego, Kultury i Dydaktyki7.

Niepodległość Litwy otworzyła możliwość nawiązania bezpośredniej współpracy z uczelniami polskimi. Dzięki niej młodzi pracownicy Wileńskiego Uniwersytetu Pedagogicznego mogli podjąć studia doktoranckie w Polsce, co wcześniej było możliwe tylko na uczelniach rosyjskich (na litewskich było to niemożliwe z powodu braku wykwalifikowanej kadry polonistycznej). Zainteresowania naukowe pracowników polonistyki WUP skierowały się wówczas na odkrywanie polskiej spuścizny literacko-kulturowej na Litwie. Zaowocowały doktoratami, a następnie publikacjami, spośród których wymienić można: R. Naruniec, Michat Baliński jako mecenas polsko-litewskich więzi kulturalnych (Warszawa 1995); J. Sawicki, Michał Römer a problemy narodowościowe na ziemiach byłego

70 Informacja ustna przekazana autorowi przez doc. dr. Mirosława Dawlewicza dnia 27 września 2011 r. w Wilnie.

71 Informacja podana przez M. Dawlewicza w trakcie II Zjazdu Naukowców Polskiego Pochodzenia z Europy Środkowo Wschodniej, który odbył się w Olsztynie i Lidzbarku Warmińskim w dniach 14-15 września 2012 r.

72 Więcej na ten temat w: M. Wakar, Tworzenie się polskiego środowiska naukowego w Wilnie (1944-1991) ekspertyza przygotowana na zlecenie Departamentu Wspótpracy Międzynarodowej Urzędu Marszałkowskiego Woj. Warmińsko-Mazurskiego, czerwiec 2011; D. Kamilewicz-Rucińska, Kształcenie nauczycieli na Litwie w szkołach z polskim językiem wykładowym (1945-2000), praca doktorska obroniona na Wydziale Pedagogicznym Uniwersytetu Warmińsko-Mazurskiego w Olsztynie w 2007 r.

73 I. Masojć, Polonistyka na Litwie po drugiej wojnie światowej, „Acta Balto-Slavica”, 2011 nr 35, s. 191.

74 Ibidem, s. 194.

75 I. Masojć, Studia polonistyczne na Wileńskim Uniwersytecie Pedagogicznym, maszynopis, s. 4.

76 H. Turkiewicz, Polonistyka Wileńskiego Uniwersytetu Pedagogicznego zaprasza!, AlMW, www.magwil.It, $2009 \mathrm{nr} 3$.

77 Informacja podana przez H. Turkiewicz w trakcie II Zjazdu Naukowców Polskiego Pochodzenia z Europy Środkowo Wschodniej, który odbył się w Olsztynie i Lidzbarku Warmińskim w dniach 14-15 września 2012 r. 
Wielkiego Księstwa Litewskiego (Toruń 1998); K. Syrnicka, Polska epigrafika nagrobna na Wileńszczyźnie. Tradycja i współczesność (Wilno-Lublin 2001); J. Szostakowski, Między wolnością a zniewoleniem. Prasa w języku polskim na Litwie w okresie od września 1939 do 1964 roku (Wilno-Warszawa 2004)78. Obok tego powstawały prace z zakresu językoznawstwa: B. Dwilewicz, Język mieszkańców wsi Bujwidzie na Wileńszczyźnie (Warszawa 1997); I. Masojć, Regionalne cechy systemu gramatycznego współczesnej polszczyzny kulturalnej na Litwie (Warszawa 2001); H. Sokołowska, Wielojęzyczność a umiejętności komunikacyjne uczniów szkół polskich na Litwie (Warszawa 2004) ${ }^{79}$.

Dydaktyka na studiach pierwszego stopnia w Litewskim Uniwersytecie Edukologicznym (które dają kwalifikację nauczyciela polonisty) nie odbiega zasadniczo od klasycznego modelu polonistycznego. Wzbogacona jest jednak o podstawy translatoryki, co wynika z założenia, iż dla polonisty na Litwie niezbędne jest biegłe władanie także jej językiem państwowym i opanowanie podstaw tłumaczenia ${ }^{80}$. Na studiach magisterskich do programu włączono natomiast treści regionalne (Życie literackie Wilna w XIX w., Życie literackie Wilna w XX w., Najnowsza literatura polska na Litwie, Polsko-litewskie związki literackie, Etnokultura Wileńszczyzny) ${ }^{81}$. Wprowadzone zostały także takie dyscypliny, jak: Teoria komparatystyki literackiej, Konteksty literatury polskiej, Polska literatura najnowsza, Leksykologia porównawcza itp. ${ }^{82}$

Od utworzenia polonistyki w Wileńskim Państwowym Instytucie Pedagogicznym (obecnym Litewskim Uniwersytecie Edukologicznym) studia ukończyło około 2000 absolwentów ${ }^{83}$. Największa liczba przyjęć na studia przypada na rok 2004, kiedy zorganizowana została grupa czterdziestoosobowa. Potem odnotowano systematyczny spadek przyjęć, który pogłębiła w ostatnich dwu latach reforma szkolnictwa wyższego. Maturzysta, który nie otrzyma tzw. "koszyka studenta”, zmuszony jest płacić 7200 lt. (ponad 7,5 tys. zł) za rok studiów. Warto zaznaczyć, iż jest to więcej niż w przypadku tak popularnych kierunków jak prawo czy zarządzanie. W listopadzie 2011 r. polonistyka na LUE obchodziła jubileusz swego pięćdziesięciolecia. Niestety jest to pierwszy rok od powstania, kiedy z powodu braku chętnych nie otwarto I roku. Aktualnie filologię polską studiuje 30 osób (5 na studiach magisterskich, 14 - na IV roku, 8 - na III roku i 3 - na II roku). Kadra polonistyczna składa się z 8 pracowników, z czego jedna osoba, prof. dr hab. Andrzej Baranow, jest Rosjaninem. Pozostałych 7 posiada stopień doktora nauk humanistycznych i reprezentuje polskie środowisko naukowe na tej uczelni. Są to: Irena Masojć, Halina Turkiewicz, Barbara Dwilewicz, Romuald Naruniec, Józef Szostakowski, Krystyna Syrnicka i Henryka Sokołowska. W związku z małą liczbą studentów wszyscy zatrudnieni są na 0,36 etatu4.

Podsumowując, podkreślić trzeba, że polskie środowisko naukowe, choć niewielkie, stale się rozwija. Jak wynika z przeprowadzonych przez autora badań, zogniskowane jest ono w Wilnie, choć jego przedstawicieli nie brak w innych litewskich ośrodkach akademickich, np. kierownikiem Katedry Politologii na Uniwersytecie Witolda Wielkiego w Kownie jest

78 I. Masojć, Studia polonistyczne, op. cit., s. 4.

79 Ibidem.

80 lbidem, s. 5

81 Ibidem.

82 H. Turkiewicz, Polonistyka Wileńskiego Uniwersytetu Pedagogicznego zaprasza!, op. cit.

83 I. Masojć, Nauczali nas wielu mądrości..., [w:] Między dawnymi i młodszymi laty... 50-lecie Wileńskiego Uniwersytetu Pedagogicznego, pod red. B. Dwilewicz i H. Turkiewicz, Wilno 2011, s. 99.

84 Informacje ustne przekazane autorowi przez dr Irenę Masojć dnia 28 września 2011 r. W Wilnie. 
członek Stowarzyszenia Naukowców Polaków Litwy, dr Andrzej Pukszto ${ }^{85}$. Nie do przecenienia są inicjatywy podjęte przez SNPL, spośród których najważniejszą jest powołanie wileńskiej filii Uniwersytetu w Białymstoku. Kształcenie studentów, organizacja konferencji, wydawanie pism naukowych i książek realizowane jest w miarę skromnych możliwości środowiska. Ponadto już drugi rok działa Akademia Trzeciego Wieku, czynnie wspierana przez naukowców związanych z SNPL ${ }^{86}$. Zmartwić może problem, jaki dotknął obydwie wileńskie polonistyki, które reforma szkolnictwa może doprowadzić do upadku. Niezbyt dobrze zaplanowane rozdzielanie tzw. "koszyka studenta” jest wobec filologii polskich krzywdzące, co domaga się interwencji środowisk naukowych z Polski, a także polskiej dyplomacji.

Istotne dla rozwoju środowiska naukowców Polaków z Litwy jest rozszerzenie oferty filii UwB o kierunki humanistyczne. Jednakże najważniejszym czynnikiem jest możliwość otrzymania pracy w zawodzie na litewskich uczelniach i w ośrodkach badawczych. Rzesze studentów polskiego pochodzenia wyjeżdżają do Polski lub dalej na zachód, gdzie już jako absolwenci budują swoje kariery w tamtejszych placówkach naukowych. Tylko możliwość pracy w rodzimych ośrodkach skłoni ich do powrotu.

POLISH ACADEMIC COMMUNITY IN THE REPUBLIC OF LITHUANIA

\section{Summary}

In this article the author presents results of his research during a research scholarship in the Lithuanian Institute of History in Vilnius in autumn 2011. The article describes the activity of the Polish scientific community in Lithuania, centered primarily in the Association of Polish Scientists in Lithuania and in several academic centers of Vilnius.

The author discusses academic initiatives of the Polish scientific community, such as the establishment of the Polish University in Vilnius or the creation of a subsidiary of the University of Bialystok. In addition, he focuses on the role of the University of Vilnius and the Lithuanian University of Educational Sciences.

The author utilizes books, scientific periodicals and the Polish-language press in Lithuania as well as in-depth interviews with a number of representatives of the Polish scientific community in Lithuania.

Keywords: Lithuania, Vilnius, Polish academic institutions

85 http://www.pmdf.vdu.It/politologijos-katedra

86 M. Grygorowicz, Seniorzy aktywni i żądni wiedzy, "Nasza Gazeta”, 27 października - 2 listopada 2011 nr 43 , s. 3 . 